\title{
Optimization the Effect of Decanter Cake with Fermented Fertilizer of Cow Urine in Edamame Growth and Yield
}

\author{
Made Deviani Duaja ${ }^{1, *}$ Elis Kartika ${ }^{2}$, Buhaira Buhaira ${ }^{3}$, Wahyuni Putri Armita ${ }^{4}$ \\ 1234 Agriculture Faculty, Universitas Jambi) \\ *Corresponding author. Email: made_deviani@unja.ac.id
}

\begin{abstract}
Decanter cake (DC) is one of the oil palm mill solid wastes that contains macro and micronutrient elements especially high Nitrogen levels. Using it as organic fertilizer could substitute half of the chemical fertilizer dose. The alternative decrease in chemical fertilizers requires nutrients from organic materials which quickly absorbed, mainly fermented cows liquid fertilizer (FLF). This research was design with Randomized Complete Block Design to evaluate the combination of DC and FLF on edamame growth and yield. The observed variables of the growth parameter are the number of branches, leaves, pods, filled pods per plant, fresh pod weight, and yield per unit area. Data were processed using analysis of variance and DMRT. The result showed, for growth parameter, the highest number of branches and leaves per plant was achieved at DC dose 20 tons ha- 1 without FLF and significant difference with DC 5 ton ha-1 with or without FLF of cow urine. Yield component, number of pods, and filled pods were achieved at DC 10 ton ha-1 with FLF $60 \%$ of cow urine concentration.
\end{abstract}

Keywords: CPO; Mill; urine; MOL; local microorganism.

\section{INTRODUCTION}

Edamame as green vegetable soybean is a specialty soybean (Glycine max (L.) Merr.). It has been widely developed, defined as a large soybean seed, which is harvested young and marketed in fresh or frozen form. The seeds of edamame varieties have high protein content, naturally gluten-free and low in calories, do not have cholesterol, and are high protein, iron, and calcium sources. In $100 \mathrm{~g}$, edamame contains $361 \mathrm{mg}$ of omega-3 fatty acids and $1794 \mathrm{mg}$ of omega- 6 fatty acids.

Edamame has a potency to cultivate in Indonesia due to market prospects, both domestic and export. Farmers planted edamame in soybean centers. Accordingly, in Jambi Province, edamame cultivation practices intercrop with vegetables. It is not the main crop, so it makes a low yield. Yield increasing needs area development, where soybean is planted because all external and internal factors for edamame growth and development requirements are the same as soybeans. However, the main problem is the soybean center are ultisol soils.
Ultisol is soil with a low $\mathrm{pH}$, organic matter content, and macro and micronutrients but high in $\mathrm{Al}$, $\mathrm{Fe}$, and $\mathrm{Mn}$ content [1]. To increase the organic matter content through liming, fertilizing, and adding organic material [2]. Organic matter additions aim to improve soil fertility and provide nutrients for plants ([3]. One organic material is waste from the palm oil mill industry; oil palm processing activities produce waste consisting of solid, liquid, and gas waste. Liquid waste comes from the sterilization process unit, clarification, and disposal from hydro cyclones, solid waste in the form of empty fruit bunches, shells, fiber, sludge, and decanter cake (DC).

DC is a solid waste from crude palm oil or palm mud processing and usually separated from the liquid. DC comes from the mesocarp of oil palm fibers that have been processed at the mill [4]. Each palm oil mill can process 1,065 tons of $\mathrm{FFB} /$ day, the processing of fresh fruit bunches one ton can produce DC as much as $4.0 \%$, or as much as $40 \mathrm{~kg}$ [5]. Palm oil mills have not utilized DC because it has to be processed and fermented at a high cost. Mill dumped the waste around the oil palm plantations, and at a certain period will accumulate and pollute the environment. Hence, 
the mill should handle it properly to avoid environmental hazards [6] \& [7]. Previous research [8] also reported on this. Therefore, it can proceed to produce bio-compound fertilizer to recycle waste.

Accordingly, the reuse of waste for agricultural purposes to improve soil properties and increase crop yield minimizes the problems [9] \&[10]. Organics wastes in agriculture play a significant role in recycling essential plant nutrients, sustaining soil security, and protecting the environment. Hence, solid waste from the oil palm factory is mainly used as a source of organic matter, improving soil properties, and microbial activity closely related to soil fertility. The organic waste of plant, supplies a good source of nutrients to enhance soil productivity [11] \& [12]). Furthermore, [13] \& [14] reported that the decanter cake (DC) has $\mathrm{N}$ content total of $4.22 \%, \mathrm{P} 2 \mathrm{O} 54.272 \mathrm{mg}$ $100 \mathrm{~g}-1$, K $2.044 \mathrm{mg} \mathrm{100g-1,} \mathrm{organic} \mathrm{C} 27.43 \%$ and pH 7.32 , and suitable for use as organic matter and a source of nutrients for Ultisols soil.

Provision decanter cake doses 15 tonnes /ha to Pak Choy plants showed the highest plant height, the highest number of leaves, and the highest fresh weight of Pak Choy [15]. Furthermore, the combination of DC and NPK gives the highest value of peanuts at DC dose of 26 tons ha-1 and NPK 50 percent of the recommended dose [16]. Similar results reported in celery plants showed DC dose 15 tons ha- 1 combined with 50 percent of NPK showed the highest soybean yield in Ultisols [17] \&[13].

In addition to providing organic material for substitute the use of chemical fertilizers through utilizing agricultural factories waste, require additional fertilizers, especially for edamame when entering the phase of pod formation [18]. Based on the description, it is necessary to add fertilizer, especially liquid fertilizer, which is easily absorbed and has microelement, growth regulators, and enzymes. Some research results show that the use of liquid organic fertilizer from livestock liquid waste is the alternative because it not only contains micronutrients but also contains growth regulators and enzymes, especially cow urine [19], [20], [21], [22], \& [23].

Cow urine as liquid fertilizers can increase enzymatic activity and lessen micronutrient deficiency in soil [24]. Accordingly, I cow urine concentration increasing will improve all phenotypic characters of the Trigonella plant [25]\& [26]. Hence, some research found that urine contains auxins $162-783 \mathrm{ppm}$ and gibberellin hormones 0-938 ppm [22] \& [27].
Furthermore, several researchers explained that fermented liquid fertilizer of cow urine contains microelements and growth regulators. It has N $2.7 \%, \mathrm{P}$ $2.4 \%$, K $3.8 \%$, Ca $5.8 \%$. Liquid fertilizer of fermented cow urine has IAA (Indol Acetic Acid) hormone that can stimulate plant growth and development and increase plant resistance to insects, pests, and diseases for eggplant [28]. Similar research describes the significant improvement of total $\mathrm{N}$, available $\mathrm{P}$, and exchangeable $\mathrm{Ca}$ dan $\mathrm{Mg}$ in the urine treatment [29]. Early research also reported the application of urine to the soil could improve soil Nitrogen [30].

Based on the description above, this research aims to utilize decanter cake as fertilizer for edamame growth and further increase the yield combined with a liquid fertilizer from fermented cow livestock was.

\section{RESEARCH METHOD}

The experiments were conducted at $-1.6042235 " \mathrm{~S}$ 103.5213307" E, in Jambi Province, at an altitude of 20 meters above sea level. Edamame seeds of Ryoko 75 variety, fermented liquid fertilizer (FLF) from cow urine, the urine was on a single day from 10 lactating cow dairy of farmers in Mandalo Darat ( -1.609290 , 103.521502). The researcher stored the urine in a jerry can with a lid in an aired shade. It started to be applied at one-month storage. DC (decanter cake in dry form and ready-to-use), previously the new form was taken from the PT Bukit Bintang Barisan Oil Palm Factory $\left(1^{\circ} 23^{\prime} 10.0\right.$ "S $\left.103^{\circ} 30^{\prime} 28.8^{\prime \prime} \mathrm{E}\right)$. This study was designed as Randomized Block Design (RBD), with treatment combination of DC and concentration of Fermented Liquid Fertilizer (FLF) based on cow urine: DC 5 tons ha-1 + 60\% FLF; DC 10 tons ha-1 + 60\% FLF; DC 15 tons ha-1 + 60\% FLF; DC 20 tons ha-1 + 60\% FLF; DC 0 tons ha- $1+60 \%$ FLF; DC 5 tons ha $1+0 \%$ FLF; DC 10 tons ha-1 + $0 \%$ FLF; DC 15 tons ha-1 + 0\% FLF; DC 20 tons ha- $1+0 \%$ FLF. The observed variables are the number of branches, leaves, pods, filled pods per plant, fresh weight, and yield per unit area. Furthermore, the data obtained were analyzed by analysis of variance and DMRT test at 5\% level.

Table 1 The nutrient content in Decanter Cake (DC)

\begin{tabular}{|c|c|}
\hline $\begin{array}{c}\text { Type of } \\
\text { analysis }\end{array}$ & Total-Content \\
\hline $\mathrm{pH}$ & 7.320 \\
\hline $\mathrm{C}$ organic & 27.43 \\
\hline $\mathrm{N}$ & 5.220 \\
\hline $\mathrm{P}$ & 4.272 \\
\hline $\mathrm{K}$ & 2.244 \\
\hline
\end{tabular}


Tabel 2. The nutrient content in fermented liquid fertilizers (FLF) of cow urine

\begin{tabular}{|c|c|}
\hline $\begin{array}{c}\text { Type of } \\
\text { analysis }\end{array}$ & Total-Content \\
\hline $\mathrm{N}$ & $6657.08 \mathrm{ppm}$ \\
\hline $\mathrm{P}$ & $12.21 \mathrm{ppm}$ \\
\hline $\mathrm{K}$ & $2738.05 \mathrm{ppm}$ \\
\hline Fe total & $562.27 \mathrm{ppm}$ \\
\hline $\mathrm{Mn}$ & $786.36 \mathrm{ppm}$ \\
\hline $\mathrm{Cu}$ & $694.32 \mathrm{ppm}$ \\
\hline $\mathrm{Zn}$ & $598.45 \mathrm{ppm}$ \\
\hline $\mathrm{B}$ & $342.21 \mathrm{ppm}$ \\
\hline $\mathrm{Co}$ & $11.00 \mathrm{ppm}$ \\
\hline $\mathrm{Mo}$ & $4.70 \mathrm{ppm}$ \\
\hline $\mathrm{IAA}$ & $5.0 \%$ \\
\hline $\mathrm{pH}$ & 8.14 \\
\hline \multicolumn{2}{|c}{}
\end{tabular}

\section{RESULT AND DISCUSSION}

\subsection{Number of Branches and Leaves per \\ Plant}

Various doses of DC combined with FLF cow urine concentration significantly affected the number of branches per plant. The highest number of branches was achieved at DC doses 20 tons ha- $1+0 \%$ of FLF concentration and significantly differed from DC doses 5 ton ha-1 with and without FLF of cow urine. Increasing the DC dose to 10 and 15 ton ha- 1 with FLF shows a significant difference. The highest number of branches was obtained in the treatment with high doses of decanter cake with FLF of cow urine or without cow urine. This shows that DC increments can obtain the highest number of edamame branches. That suggests edamame plant need more of DC dose if no fermented liquid fertilizers of cow urine adding, this is due to the content of Nitrogen in DC and cow urine, also the influence of hormonal effect, the presence of auxin (AIA) in cow urine [31] and [21]). The hormonal effect, influence a faster absorption of $\mathrm{N}$ through the cuticula than the other components [32]

Table 3 Number of branches and leaves at several DC doses and FLF concentrations



Note: Figures in columns followed by different letters show a significant difference at level 5\% of DMRT

The result of DC content shows that macro and micronutrients, especially $\mathrm{N}$ content, are relatively high. This effect will stimulate early plant growth and development, even though $\mathrm{P}$ and $\mathrm{K}$ levels are low, and with the increasing plant age, other nutrients are also needed. According to [33], plants needed potassium more, especially in the pod formation phase. There is a close relationship between $\mathrm{K}$ levels in the tissue with $\mathrm{CO} 2$ assimilation in plants [34]. Furthermore, if the plant experience on potassium is deficient, it inhibits carbohydrate translocation to another plant organ. So, photosynthates will accumulate in the leaves and reduce the photosynthesis rate.
Various doses of DC and FLF concentration significantly affected the number of leaves. The highest leaves number was achieved at 20 tons ha- 1 of DC + FLF $0 \%$ and has the same effect with a dose of 10,15 , and 20 tons at 60 percent of FLF concentration of cow urine. It indicates that the highest number of leaves must be at a high DC dose level, 20 tons ha-1 if no adding of cow urine. Decanter cake is the prime $\mathrm{N}$ source, and the effect is to stimulate an increase in leaves number and plant height with $\mathrm{N}$ increase. Hence, it also found a significant decrease in eggplant stem thickness when $\mathrm{N}$ absent [35]. Incorporation of organic matter in the soil (DC) and FLF of cow urine as liquid fertilizers substantially improves plant growth 
and development [36]. This is due to the many beneficial elements has in decanter cake and FLF of cow urine (Table 2). These results support previous research conducted by [25] and [21]; cattle urine is a primary source of Nitrogen and other macro and micronutrient.

According to [37], cow urine has not only nutrients but also rich plant growth substances. Cow urine contains $95 \%$ water, $2.5 \%$ urea, and the remaining $2.5 \%$ a mixture of salts, hormones, enzymes, and minerals [38]. The other cow urine research concluded that cow urine contained nutrients in high concentration, especially Phosphorus, and the positive effect cow urine supplied essential plant nutrients and keep the soil fertile and stimulate crop growth and yield
[10]. Furthermore, cow manure usage could increase plant height, leaf number, and plant dry weight. Some researchers also reported that cow urine concentrations increase all lettuce characteristics like fresh and dry leaf mass, fresh and dry stem mass, stem length, fresh root mass, fresh head mass, and commercial yield [39].

\subsection{Number of Pods and Filled Pods per Plant}

Various DC doses and FLF concentrations of cow urine significantly affected the number of pods per plant, and the highest performance was obtained at DC dose of 10 tons ha-1 + FLF $60 \%$ and significantly different from other treatments.

Table 4. Number of pods, filled pods and fresh pod weight per plant at several of DC dose and FLF concentration

\begin{tabular}{|c|r|r|c|}
\hline $\begin{array}{c}\text { Various of DC dose and } \\
\text { PC concentration }\end{array}$ & $\begin{array}{r}\text { Number of Pods } \\
\text { 0 to/ha + FLF 0\% }\end{array} \quad 9.64$ c & $\begin{array}{c}\text { Number of Filled } \\
\text { Pods per Plants }\end{array}$ & Weight of Fresh Pods \\
\hline 5 ton/ha + FLF 60\% & $17.38 \mathrm{~b}$ & $14.82 \mathrm{~b}$ & $61.69 \mathrm{c}$ \\
\hline 10 ton/ha + FLF 60\% & $29.84 \mathrm{a}$ & $24.56 \mathrm{a}$ & $175.18 \mathrm{~b}$ \\
\hline 15 ton/ha + FLF 60\% & $18.93 \mathrm{~b}$ & $14.91 \mathrm{~b}$ & $392.03 \mathrm{a}$ \\
\hline 20 ton/ha + FLF 60\% & $18.60 \mathrm{~b}$ & $16.48 \mathrm{~b}$ & $254.07 \mathrm{~b}$ \\
\hline 0 ton/ha + FLF 60\% & $10.03 \mathrm{c}$ & $8.23 \mathrm{c}$ & $152.15 \mathrm{~b}$ \\
\hline 5 ton/ha + FLF 0\% & $15.92 \mathrm{~b}$ & $15.66 \mathrm{~b}$ & $99.59 \mathrm{bc}$ \\
\hline 10 ton/ha + FLF 0\% & $21.30 \mathrm{~b}$ & $12.36 \mathrm{~b}$ & $117.23 \mathrm{~b}$ \\
\hline 15 ton/ha + FLF 0\% & $15.36 \mathrm{~b}$ & $14.22 \mathrm{~b}$ & $146.22 \mathrm{~b}$ \\
\hline 20 ton/ha + FLF 0 \% & $17.83 \mathrm{~b}$ & $15.37 \mathrm{~b}$ & $174.17 \mathrm{~b}$ \\
\hline
\end{tabular}

Note: Figures columns followed by different letters show a significantly Difference at level 5\% of DMRT

Edamame is harvested at reproductive stage R6 when the seeds are immature and have expended to fill $80 \%$ of the pod width when pods are filled. The number of edamame pods per plant, influenced by decanter cake+FLF cow urine, the development of edamame pods is very dependent on the number of insoluble nutrients. These nutrients are only obtained from decanter cake with the increasing plant age to generative phase, decanter cake (DC) as organic materials in mineralization process producing organic acids that can solve insulated Al-P or Fe-P compounds into soluble. It can affect the solubility of Al-dd and the availability of $\mathrm{P}$, increase the availability of $\mathrm{P}$ in soil solution, will stimulate the absorption of $\mathrm{P}$ by plants. According to [40] and [41], the effect of organic matter on P's availability could directly employ through the process of mineralization. Additionally, an indirect manner could be practised by assisting P's release, fixation of P. However; it is not enough for pod filling; it must be added nutrient and hormone low and absent in the decanter cake. Therefore, liquid fertilizer from cow urine is needed because of the nutrient and IAA hormone content. [42] reported cow urine application on chickpea after flowering gives the highest number of pods per plant, and [39] reported increased maximum maize grain yield.

\subsection{Edamame Yield}

Various doses of DC and PC concentration of cow urine shows significantly affected the yield of edamame $\mathrm{p}$. The highest yield was achieved at a dose of 10 tons ha- $1+$ FLF $60 \%$. The number of pods supports the high yield achieved and the number of filled pods and fresh pods' weight. Accordingly, there are indications that for vegetative growth, the nutrients obtained from a decanter cake dose of 20 tons/ha $+0 \%$ FLF of cow urine. It was sufficient because the age of edamame until the V4 stages is quite short, but for the next stages, which is the stages of pods formation and filling, need the addition of other nutrients from cow urine liquid fertilizer. Cow urine is suitable for 
adding nutrients because the nutrient content of Phosphorus and potassium are quite high. The highest fresh pod weight was achieved at 10 tons/ha+ FLF 60\% and significantly different from the other treatments. This indicates when combined with FLF cow urine, decanter cake (DC) used is sufficient at low doses.

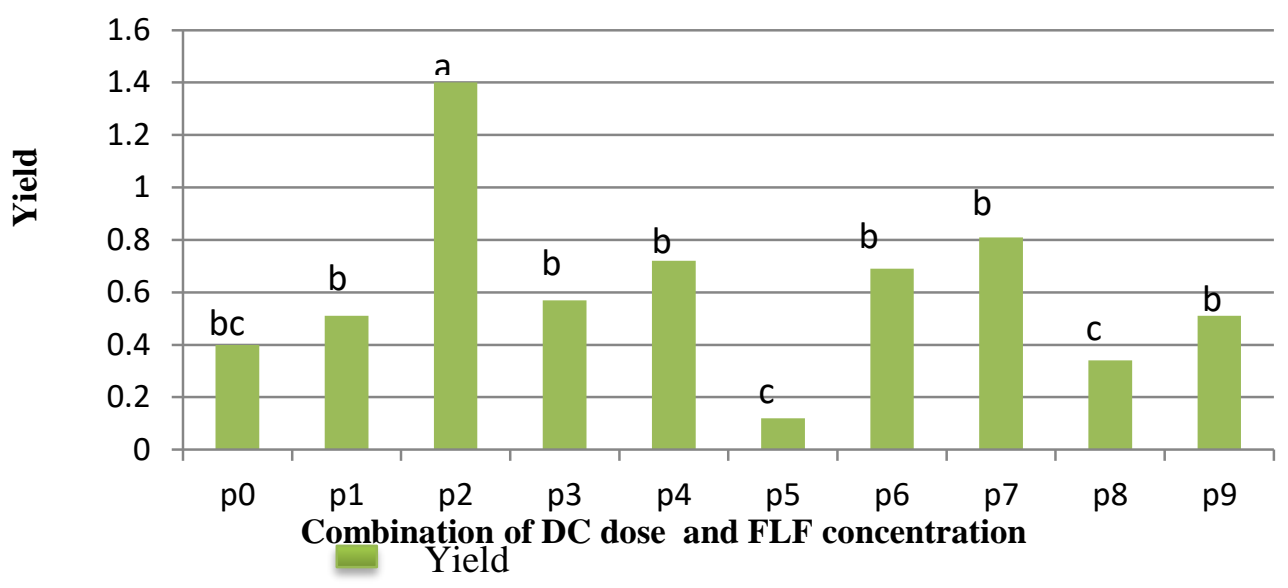

Figure 1 Graph of yield per hectare at several of DC dose and FLF concentration

Note:

\begin{tabular}{|c|c|}
\hline$p_{0}$ & $n h a^{-1}+F L F$ \\
\hline $\mathrm{p}_{1}$ : & DC 5 ton $\mathrm{ha}^{-1}+$ FLF $60 \%$ \\
\hline$p_{2}:$ & DC 10 ton $\mathrm{ha}^{-1}+$ FLF $60 \%$ \\
\hline & DC 15 ton $\mathrm{ha}^{-1}+$ FLF 60 \\
\hline 4 & DC 20 ton $\mathrm{ha}^{-1}+$ FLF $60 \%$ \\
\hline
\end{tabular}

The highest fresh Pods weight and yield per unit area was achieved at combination DC and cow urine FLF. The present research of [43] reported a combination of organic material with cow urine significantly affect growth parameter and yield of paddy crops. Similarly, [44] recorded the highest maize grain yield was achieved at combination cow urine and organic material "panchagavya". This phenomenon indicates that decanter cake in low doses not sufficient for edamame at R5-R6 stages; therefore, it must be combined with other nutrient sources which are more easily absorbed by plants.

\section{CONCLUSION}

Decanter cake is a palm oil mill solid waste that contains high nutrient elements, especially Nitrogen level and the other elements. Using Decanter as organic fertilizer is not sufficient for early edamame growth; therefore, it is necessary to add nutrients so readily available and absorbed by plants. The DC decomposition process can supply pod formation, pod filling, and pod yield in the generative phase. Therefore, at the vegetative stage, a decanter cake is sufficient in high doses without cow urine or low doses but with cow urine.

\begin{tabular}{|c|c|}
\hline$p_{5}:$ & $D C 0$ ton ha- ${ }^{1}+$ FLF $60^{\circ}$ \\
\hline & DC 5 ton $\mathrm{ha}^{-1}+$ FLF $0 \%$ \\
\hline & $\mathrm{ha}^{-1}+\mathrm{FLF} 0 \%$ \\
\hline & $\mathrm{ha}^{-1}+\mathrm{FLF} 0 \%$ \\
\hline & DC 20 ton $\mathrm{ha}^{-1}+$ FLF $0 \%$ \\
\hline
\end{tabular}

Finally, the addition of nutrients from organic materials and liquid organic fertilizer from cow's liquid waste supports some growth measurement.

\section{AUTHORS' CONTRIBUTIONS}

Each author in this research provided input and contribution. The first author determines the treatment schedule, participates in the discussion, and writing of articles. The second author mainly contributes in data analysis and discussion. And the third and fourth authors contribute to planting, treatment, collecting data and harvesting and discussing all the data and interpretation.

\section{ACKNOWLEDGMENT}

Great appreciation to the Faculty of Agriculture, Universitas Jambi for research grant Scheme Applied Research. My thankfulness is also directed to Kelompok Tani Suka Maju. for the assistance throughout the research. 


\section{REFERENCES}

[1] B. H. \& S. Prasetyo, "Karakteristik, Potensi, dan Teknologi Pengelolaan Tanah Ultisol untuk Pengembangan Pertanian Lahan Kering di Indonesia," J. Litbang Pertanian, 25(2), 2006, vol. 25, no. 2, pp. 39-47, 2006.

[2] E. C. H. A. Okalia, Deno, "The Influence of Various Dosages of Compost Solid Plus (Kosplus) on Improving The Soil Chemistry Ultisols In Kuantan Sengigi," J. Agroqua Media Inf. Agron. dan Budid. Perair., vol. 15, no. 1, pp. 8-19, 2017.

[3] Setiawati, Murtiningsih, Sopha, and Handayani, Petunjuk Teknis Budidaya Tanaman Sayuran, 1st ed. Jl. Ir. H. Juanda No. 20 Bogor: Pusat Perpustakaan dan Penyebaran Teknologi Pertanian Kementerian Pertanian, 2007.

[4] B. N. Utomo and E. Widjaja, "Limbah padat pengolahan minyak kelapa sawit sebagai sumber nutrisi ternak ruminansia," J. Litbang Pertan., vol. 23, no. 1, pp. 22-28, 2004.

[5] M. D. Duaja, E. Kartika, and L. Lizawati, "Application of Indigenous AMF from ex-coal Mining Soil Combined with Phosphorus Fertilizers to Improved Oil Palm Seedling Growth (Elaeis guineensis Jacq.)," Biog. J. Ilm. Biol., vol. 7, no. 1, 2019

[6] R. P. Singh and M. Agrawal, "Effect of Different Sewage Sludge Applications on Growth and Yield of Vigna radiata L. Field Crop: Metal Uptake by Plant," Ecol. Eng., vol. 36, no. 7, pp. 969-972, 2010, doi: $10.1016 /$.

[7] A. Embrandiri, M. H. Ibrahim, and R. P. Singh, "Palm Oil Mill Wastes Utilization; Sustainability in the Malaysian Context," Int. J. Sci. Res. Publ., vol. 3, no. 1, pp. 2250-3153, 2013.

[8] K. Haron, A. T. Mohammed, R. Mohamed Halim, and A. K. Din, "Palm-based Bio-fertilizer from Decanter Cake and Boiler Ash of Palm Oil Mill," Inf. Ser. (MPOB TT No. 412), pp. 1-4, 2008.

[9] A. Embrandiri, R. P. Singh, and M. H. Ibrahim, "Biochemical, Morphological, and Yield Responses of Lady's Finger Plants to Varying Ratios of Palm Oil Mill Waste (Decanter Cake) Application as a Bio-fertilizer," Int. J. Recycl. Org. Waste Agric., 2013, doi: 10.1186/2251-7715-2-7.

[10] M. Z. Hossain, P. V. F. Niemsdorff, and J. Heß, "Effect of Different Organic Wastes on Soil Properties and Plant Growth and Yield : a Review," vol. 2017 , no. 4 , pp. $224-237$, 2017, doi: $10.1515 /$ sab2017-0030.
[11] J. G. M. Tejada, "Effects of Two Beet Vinasse Forms on Soil Physical Poperties and soil loss ScienceDirect," CATENA, vol. 68, no. 1, pp. 41-50, 2006.

[12] M.Tejadaa J.L.Morenob M.T.Hernandez C.Garciab, "Application of Two Beet Vinasse Forms in Soil Restoration Effects on Soil Properties in an Arid Environment in Southern Spain - ScienceDirect," Agric. Ecosyst. Environ., vol. 119, no. 3-4, pp. 289298, 2007.

[13] M. D. Duaja, "Response Of Celery Plant (Apium graviolens L.) To The Reduction Of Inorganic Fertilizers With Decanter Cake Usage," Agric, vol. 31, no. 1, pp. 31-40, 2019.

[14] D. Duaja, M.D, Kartika, E., \& Fransisca, "Utilization of Palm Oil Mill Solid Waste and Inorganic Fertilizers on Chinese Kale (Brassica alboglabra) In Ex Coal Mining Soil," Agric, 32(1), vol. 32, no. 1, 2020.

[15] L. R. Gustianty and S. Hasibuan, "Pengaruh Pupuk Solid Dan Sekam Padi Terhadap Tempat dan Waktu Penelitian," J. Penelit. Bernas, vol. 1301, no. 01, pp. 22-30, 2017.

[16] D. setiawan Damanik, Murniati, and Isnaini, "the Effect of Solid Palm Oil and NPK on Growth and Production," JOM Faperta, vol. 4, no. 2, pp. 1-13, 2017.

[17] M. D. Duaja, E. Kartika, and B. Buhaira, "Response of Soybean (Glycine Max) to The Reduction of Inorganic Fertilizer with Palm Oil Factory Waste Decanter Cake," in IOP Conference Series: Earth and Environmental Science, 2019, Vol. 391.

[18] S. Sufardi and T. Arabia, "Proceeding Of International Workshop And Seminar Innovation of Environmental-Friendly Agricultural Technology Supporting Sustainable Food Self-Sufficiency Soil physical and chemical ...," no. April, 2012,

[19] N. L. C. de Oliveira, M. Puiatti, R. H. S. Santos, P. R. Cecon, and P. H. R. Rodrigues, "Soil and leaf fertilization of lettuce crop with cow urine," Hortic. Bras., vol. 27, no. 4, pp. 431-437, 2009.

[20] N. D. Devakumar, S. Shubha, G. G. E. R. Ro, and Imrankhan, "Studies on Soil fertility, Cow urine and Panchagavya levels on Growth and Yield of Maize," in Proceedings of the 4th ISOFAR Scientific Conference. 'Building Organic Bridges', at the Organic World Congress 2014, 13-15 Oct., Istanbul, Turkey (eprint ID 23358), 2014, pp. 13 15 ,

[21] S. Pradhan, Swati, S. Verma, S. Kumari, Y. Singh, and C. Swati Swayamprabha Pradhan, "Bio-efficacy 
of cow urine on crop production: A review," $\sim 298$ Int. J. Chem. Stud., Vol. 6, no. 3, pp. 298-301, 2018.

[22] Mariyatul Qibtiyah, "The Effect of Application Time and Dosage of Biourine on Growth and Production of Rice (Oryza Sativa L.) \n," IOSR J. Agric. Vet. Sci., Vol. 8, no. 1, pp. 26-30, 2015.

[23] S. Choudhary, M. Kushwaha, S. Preeti Singh, and R. S. Sunil Kumar, "Cow Urine: A Boon for Sustainable Agriculture," Int. J. Curr. Microbiol. Appl. Sci., vol. 6, no. 2, pp. 1824-1829, 2017.

[24] S. N. Singh, K. K. Maurya, and G. P. Singh, "Effect Of Cow Urine (Gomutra) As A Source Of Nitrogen On Growth, Yield And Nitrogen Uptake In Rice (Oryza sativa L.)," Int. J. Microbiol. Res., vol. 10, no. 3 , p. $1035,2018$.

[25] S. Jandaik, P. Thakur, and V. Kumar, "Efficacy of Cow Urine as Plant Growth Enhancer and Antifungal Agent Efficacy of Cow Urine as Plant Growth Enhancer and Antifungal Agent," $A d v$. Agric., vol. Volume 201, no. November 2015.

[26] V. B. Karale, P. B. Khilari, and D. D. Ingole, "Effect of Cow Urine on Fertility Levels of Wheat ( Triticum aestivum ) and its Liquid Spray on Growth and Yield of Wheat ( Triticum aestivum ).," Int. J. Creat. Res. ThoughtThought (IJCRT), vol. 8, no. 3, pp. 114-117, 2020.

[27] Y. Nuraini, "Peningkatan Kualitas Biourin Sapi dengan Penambahan Pupuk Hayati dan Molase serta Pengaruhnya terhadap Pertumbuhan dan Produktivitas Pakchoy," Vol. 8, no. 3, pp. 183-191, 2017.

[28] M. I. I. : 42154h@gmail. com1)Departmen. of A. M. Azisah1), "The Influence of Organic Fertilizer from Cattle Urine on Growth and Production of Eggplant (Solanum melongenaL.)," J. Agrotan 3(2) 80-91, vol. 3, no. 2017, pp. 80-91, 2017.

[29] J. N. Nwite, "Effect of Biochar on Selected Soil Physical Properties and Maize Yield in an Ultisol in Abakaliki Southeastern Nigeria," Int. J. Adv. Agric. Res., vol. 3, no. 12, pp. 31-36, 2015.

[30] R. Gutser, T. Ebertseder, A. Weber, M. Schraml, and U. Schmidhalter, "Short-term and Residual Availability of Nitrogen After Long-term Application of Organic Fertilizers on Arable Land," J. Plant Nutr. Soil Sci., vol. 168, no. 4, pp. 439-446, 2005.

[31] N. Mappanganro, U. A. M. Jurusan Biologi, Fakultas Sains dan Teknologi, K. G. 92113 Jl. Sultan Alauddin 36 Samata, and E. Ilha_k@yahoo.co.id, "Efect of Cattle Urine Sprays on Yield and Quality of Mango (Mangifera Indica) cv Alfonso," TJurnal Biog., Vol. 1, no. 2, 2013, [Online].

[32] A. Khanal, S. Shakya, and M. Sharma, "Utilization Of Urine Waste To Produce Quality Cauliflower," J. Agric. Environ., vol. 12, pp. 91-96, 2013.

[33] Subandi, "Peran Dan Pengelolaan Hara Kalium Untuk Produksi Pangan Di Indonesia," Agric. Innov. Dev., vol. 6, no. 1, pp. 1-10, 2013

[34] E. A. Mengel, , Kirkby, Principles of Plant Nutrition | Konrad Mengel | Springer, 5th ed. Netherlands: Springer Netherlands, 1987

[35] M. O. Cardoso, A. P. De Oliveira, W. E. Pereira, and A. P. De Souza, "Growth, nutrition and yield of eggplant as affected by doses of cattle ma- nure and magnesium thermophosphate plus cow urine," vol. 2, pp. 307-313, 2009.

[36] E. J. Kiehl, Fertilizantes organicos. 1985.

[37] K. Rajesh and Jayakumar, "Changes in Morphological, Biochemical and Yield Parameters of Abelmoschus esculents (L.) Moench due to Panchagavya Spray," Int. J. Mod. Plant Anim. Sci., vol. 1, no. 2, pp. 82-95, 2013, [Online].

[38] S. Rekha, G. Rakshapal, and O. Rout, "Review Article Benefits of Cow Urine - a Review," Int. J. Recent Adv. Multidiscip. Res., vol. 04, no. October, pp. 2833-2835, 2017,

[39] N. Devakumar, S. Shubha, and G. G. E. Rao, "Studies on soil fertility, Cow urine and Panchagavya levels on Growth and Yield of Maize," p. 627, 2014, [Online].

[40] F. J. Stevenson, Humus Chemistry Genesis, Composition, Reactions, 2nd Editio. published by Wiley.

[41] K. A. Hanafiah, "Dasar - dasar ilmu tanah _ Kemas Ali Hanafiah Dinas Kearsipan dan Perpustakaan Provinsi Sumatera Barat."

[42] S. V Patil et al., "Effect of organics on growth and yield of chickpea ( Cicer arietinum L .) in vertisols *," vol. 25 , no. $3,2012$.

[43] B. Feri Andreeilee, M. Santoso, and M. Dawam Maghfoer, "The Effect of Organic Matter Combination and Azola Dosage ( Azolla pinnata ) on Growth and the Production of Paddy ( Oryza sp.) Ciherang Variety ," Res. J. Agron., vol. 9, no. 1, pp. $1-4,2019$.

[44] N. Devakumar, S. Shubha, and G. G. E. Rao, "Studies on soil fertility, Cow urine and Panchagavya levels on Growth and Yield of Maize," p. $627,2014$. 